\title{
Kualitas produk Virgin Coconut Oil (VCO) menggunakan teknik mekanik skala industri rumah tangga
}

\section{Product quality of Virgin Coconut Oil (VCO) by using household industry scale mechanical techniques}

\author{
Sukma Budi Ariyani ${ }^{{ }^{*}}$, Haqqifizta Ratihwulan ${ }^{a}$ dan Asmawit ${ }^{a}$ \\ Baristand Industri Pontianak Jln. Budi Utomo No. 41 Pontianak 78243 \\ E-mail : sukma_ariyani@yahoo.co.id
}

Diterima 25 Agustus 2021, Direvisi 17 Desember 2021, Disetujui 20 Desember 2021

\begin{abstract}
ABSTRAK
Virgin Coconut Oil (VCO) merupakan produk unggulan hasil olahan kelapa yang memiliki banyak kegunaan terutama di bidang kesehatan untuk mengatasi penyakit degeneratif. Ketersediaan kelapa yang melimpah belum dimanfaatkan secara optimal oleh industri rumah tangga VCO di Kalimantan Barat. Pembuatan VCO dengan cara teknik mekanik memiliki kelebihan yakni sederhana, hemat bahan bakar (tanpa pemanasan) dan tanpa penambahan zat aditif. Penelitian ini bertujuan memperoleh VCO dengan cara teknik mekanik (penggunaan alat blender untuk pemecahan) skala industri rumah tangga dan mengetahui kualitas VCO yang dihasilkan. Metode penelitian yang dilakukan meliputi produksi VCO dan pengujian kualitas VCO yaitu penampakan, penentuan bilangan iod, bilangan peroksida, dan asam-asam lemak. Variabel berubah yang digunakan adalah lama waktu proses teknik mekanik dengan menggunakan alat blender (5, 10 dan 15 menit). Hasil yang diperoleh dalam penelitian ini adalah kenampakan fisik untuk VCO yang dihasilkan jernih dan transparan. Rendemen VCO tertinggi yang dihasilkan yakni pada variabel lama waktu proses mekanik (blender) 10 menit. VCO yang dihasilkan pada semua variabel memenuhi persyaratan yang ditetapkan (SNI 7381:2008) untuk parameter bilangan iod, bilangan peroksida, asam lemak bebas, kadar asam laurat, kadar asam oleat dan kadar linoleat. Untuk kadar asam miristat pada VCO dengan variabel lama waktu blender 5 menit di bawah standar yang ditetapkan yakni 16,63 \%, sedangkan kadar asam miristat untuk VCO dengan lama waktu blender 10 dan 15 menit hasilnya memenuhi syarat yang ditetapkan yaitu secara berturut-turut $17,66 \%$ dan $18,71 \%$.
\end{abstract}

Kata Kunci : kualitas; mekanik; VCO

\section{ABSTRACT}

Virgin Coconut Oil (VCO) is a prime product from processed coconut that has many uses, especially in the health sector to overcome degenerative diseases. The availability of coconut has not been optimally used by the VCO household industries in West Kalimantan. Production of VCO by using mechanical techniques has many advantages, for instance simple, low cost, and without any addition of additives. This study aimed to obtain VCO by using mechanical techniques (with blender for crushing) for household industry scale and determine the product quality. The research methods contain VCO production and evaluation of VCO quality with determination of visualization, iodine number, peroxide number, and fatty acids. Independent variable used is mechanical time with the blender (5, 10, 15 minutes). The results showed the physical appearance of the VCO was clear and transparent. The highest yield of VCO produced by 10 minutes of mechanical time. Determination of iodine number, peroxide number, free fatty acid, lauric acid, oleic acid, and linoleic acid content conform to SNI 7381:2008 requirements. The myristic acid with 5 minutes mechanical time showed under the standard, while 10 and 15 minutes mechanical time fit with the standard, that is $17.66 \%$ and $18.71 \%$. 
Keywords : mechanical; quality; VCO

\section{PENDAHULUAN}

Kelapa merupakan komoditas perkebunan yang serbaguna. Tiap komponen dari buah kelapa umumnya dapat digunakan baik sebagai sumber pangan maupun non-pangan. Kandungannya berupa air, daging, tempurung, dan sabut (Tabel 1) yang masing-masing mempunyai peluang besar untuk dikembangkan dan menghasilkan produk yang berdaya guna. Contohnya, air kelapa yang dapat menghasilkan nata de coco, vinegar, kecap; daging kelapa menghasilkan virgin coconut oil, minyak goreng, oleokimia, bungkil; tempurung kelapa menghasilkan tepung, arang aktif; dan sabut menghasilkan serat berkaret dan geotextile (Mahmud dan Ferry 2005).

Tabel 1. Persentase tiap bagian kelapa Bagian buah kelapa Persentase

\begin{tabular}{ll}
\hline Sabut & $35 \%$ \\
\hline Daging buah & $28 \%$ \\
\hline Air kelapa & $15 \%$ \\
\hline Tempurung & $12 \%$ \\
\hline $\begin{array}{l}\text { Bagian lain (pangkal buah, } \\
\text { kulit luar, Lembaga, testa) }\end{array}$ & $10 \%$ \\
\hline
\end{tabular}

Sumber: (Asmawit, 2010)

Kelapa dalam (Cocos nucifera) merupakan salah satu varietas unggul kelapa selain kelapa genjah, kelapa hibrida, dan kelapa kopyor. Kelapa dalam sering ditemui di berbagai daerah, khususnya daerah subtropis dan tropis, termasuk Indonesia. Pertumbuhan kelapa yang baik berada pada ketinggian 0-600 m di atas permukaan laut, suhu rata-rata $25^{\circ} \mathrm{C}$ dan kelembaban $80-95 \%$ (Asmawit, 2010). Kalimantan Barat, merupakan daerah dengan sumber daya kelapa dalam yang melimpah. Hal ini ditunjukkan dengan produksinya yang tiap tahun kian meningkat. Pada tahun 2019, produksi kelapa dalam mencapai 81.301 ton (BPS Kalbar, 2019).

Salah satu hasil pemanfaatan kelapa dalam sebagai produk pangan maupun farmasi yaitu Virgin Coconut Oil (VCO). Produk VCO merupakan salah satu jenis minyak nabati dari kelapa yang sangat populer di dunia. VCO telah dikembangkan sejak tahun 2000 awal, banyak diteliti dan menjadi unggul karena terbukti memiliki banyak manfaat kesehatan untuk manusia, diantaranya sebagai obat dan dipercaya untuk menyembuhkan penyakit degeneratif. Kebutuhan VCO semakin meningkat tiap tahunnya karena kepercayaan masyarakat terhadap VCO sebagai produk kelapa yang paling berharga. Amerika Serikat, Korea, Jepang dan berbagai negara maju lainnya bahkan mengimpor VCO dari Filipina sebanyak 4914 ton di 2011, meningkat menjadi 36.332 ton di tahun 2015. Untuk Indonesia sendiri, industri kecil dan menengah VCO mencapai lebih dari 200 industri yang menjual produk di dalam negeri (Rethinam, 2019). Berbagai pengaplikasian VCO pada produk banyak ditemukan di pasaran. Hingga saat ini, VCO digunakan sebagai conditioner rambut dan kulit, produk kosmetik dan perawatan kulit berbahan dasar minyak, minyak pembawa untuk aromatherapy, serta nutraceutical dan pangan fungsional (Arisanti dan Angelia, 2020).

VCO dihasilkan dari ekstraksi secara mekanik maupun alami dari kopra yang terdapat pada inti kelapa segar dengan atau tanpa menggunakan aplikasi panas, yang pengolahannya tidak mengubah kandungan nutrisi pada minyak (Agarwal dan Bosco, 2017). Berbeda dengan minyak kelapa RBD (refined, bleached, deodorized), VCO diproduksi tanpa melalui proses pemurnian, penjernihan, dan penghilangan aroma tak sedap. Berbagai metode dapat digunakan untuk ekstraksi VCO pada kelapa dalam. Salah satu metode yang biasa diaplikasikan yakni dengan perebusan santan dalam selang waktu tertentu hingga diperoleh minyak kelapa. Perebusan mengakibatkan kualitas minyak yang tidak dapat bertahan lama karena cepat berbau tengik dan penampakan warna menjadi coklat. Hal tersebut disebabkan oleh proses oksidasi yang terjadi karena proses oksidasi saat pemanasan (Rindawati et al., 2014). 
Dalam penelitian ini, metode yang digunakan untuk pembuatan VCO adalah teknik mekanik sesuai prosedur Wardani (2007) dengan sedikit modifikasi. Prinsip yang dilakukan seperti metode lainnya dengan melibatkan pemisahan komponen dalam santan kelapa yaitu ikatan emulsi dengan protein sebagai emulgator dan air. Masing-masing komponen yaitu minyak, protein, air akan terkumpul secara terpisah akibat ikatan yang lepas. Untuk memisahkan minyak kelapa dengan bahan lainnya dapat dilakukan dengan beberapa cara diantaranya secara mekanik. Metode mekanik dengan cara pengadukan merupakan metode pemecahan emulsi. Metode ini memanfaatkan gaya mekanik dengan adanya putaran pada pengadukan sehingga terjadi pemecahan emulsi dan dihasilkannya VCO. Pengadukan ini merupakan metode yang sederhana serta mudah dalam pengolahannya (Muslihin \& Riyani, 2018). Proses yang sederhana, murah karena tanpa bahan bakar sehingga tidak memerlukan panas, serta tanpa penambahan zat aditif (Dali et al., 2015). Mekanisme yang terjadi pada pembuatan VCO secara mekanik ini adalah dengan merusak protein dan air yang menyelimuti minyak sehingga minyak dapat keluar (Alit Prakoso et al., 2010).

Kelimpahan kelapa dalam di Kalimantan Barat belum sepenuhnya dapat dimanfaatkan oleh petani kelapa dalam. Padahal, VCO hasil kelapa dalam dibandingkan kelapa jenis lainnya memiliki kandungan asam laurat lebih tinggi (Novarianto dan Tulalo, 2007). Pada penelitian ini dilakukan pembuatan VCO dengan teknik mekanik menggunakan blender sebagai modifikasi penelitian Wardani (2007) yang melakukan pengadukan selama $5,10,15,20$, dan 25 menit. Produksi VCO oleh Wardani (2007) dinilai mudah dalam pengaplikasian skala industri rumah tangga oleh produsen di Kalimantan Barat. Teknologi yang diaplikasikan ini sesuai dengan skala operasi, kemampuan alat, jumlah investasi, serta permintaan calon pembeli. Petani kelapa dalam di Kalimantan Barat sendiri memiliki keterbatasan dalam teknologi dan investasi, untuk itu diperlukan metode yang dinilai mudah dan murah untuk menghasilkan VCO yang sesuai standar. Hasil penelitian Wardani (2007) sebelumnya menunjukkan waktu pengadukan optimal selama 15 menit dan menurun pada menit ke-20 dan selanjutnya. Oleh karena itu, penelitian ini bertujuan untuk memperoleh VCO dengan cara teknik mekanik (penggunaan alat blender sebagai fungsi pemecah, pengaduk, dan pencampur) dan evaluasi kualitas hasil VCO dengan waktu mekanik selama 5, 10, dan 15 menit.

\section{BAHAN DAN METODE}

\subsection{Alat dan Bahan}

Bahan utama pada penelitian ini adalah kelapa dalam (Cocos nucifera, Linn). Sedangkan alat yang digunakan adalah mesin parut (lokal, diameter mata parut 4 inchi, motor penggerak JY09A/4 hp, rpm $1400 \mathrm{r} / \mathrm{min}$, phase $220 \mathrm{~V}$, kapasitas 170 butir/jam), alat pemeras hidrolik (lokal, motor penggerak manual, kapasitas $\pm 3 \mathrm{~kg}$ ), blender (Phillips), dan alat analisis kimia lainnya.

\subsection{Metode}

\subsubsection{Pembuatan Virgin Coconut Oil (VCO)}

Prosedur Pembuatan VCO dalam penelitian ini merupakan modifikasi dari prosedur penelitian (Wardani, 2007). Pertama, daging buah kelapa dalam (Cocos nucifera, Linn) dipisahkan dari kulit dan dicuci sampai bersih. Kelapa diparut menggunakan mesin parut dan ditampung dalam wadah. Selanjutnya yaitu proses pembuatan santan dengan mencampur kelapa parut dan air hangat $50{ }^{\circ} \mathrm{C}$ dengan perbandingan air:kelapa parut $=2: 1(\mathrm{v} / \mathrm{v})$. Santan diperas menggunakan pemeras hidrolik. Kemudian, skim dan krim dipisahkan dengan mendiamkan santan. Waktu yang diperlukan untuk memisahkan krim dan skim santan yaitu 30 menit terlihat komponen krim akan berada di atas skim karena berat jenis yang lebih ringan. Krim diambil dan diblender selama 5, 10, dan 15 menit dan hasilnya didiamkan selama 22 jam. Setelah pendiaman, minyak akan 
berada di atas lapisan protein dan air. Terakhir, penyaringan menggunakan kertas saring Whatman kasar dengan 4 kali penyaringan.

VCO yang dihasilkan dengan variasi waktu pengolahan dengan blender selama 5 , 10, dan 15 menit dianalisis sifat fisikokimianya yang meliputi bilangan iod, bilangan peroksida, dan asam-asam lemak.

\subsubsection{Bilangan lod}

Penentuan bilangan iod dilakukan mengacu pada metode AOAC (2000). Sebanyak $1 \mathrm{~g}$ VCO dimasukkan ke dalam erlenmeyer $500 \mathrm{ml}$, ditambahkan sebanyak $15 \mathrm{ml}$ pelarut (sikloheksana : asam asetat, $1: 1)$, ditambahkan larutan wijs sebanyak 25 $\mathrm{ml}$. Setelah 1-2 jam didiamkan dalam ruang gelap, ditambahkan larutan $\mathrm{KI} 20 \%$ dan $100 \mathrm{ml}$ akuades. Larutan dititrasi dengan larutan standar natrium tiosulfat $0,1 \mathrm{~N}$ dengan indikator berupa larutan kanji. Hasil titrasi dihitung dengan rumus sebagai berikut:

$$
\begin{aligned}
\text { Bilangan iod }=\frac{(V 0-V 1) \times N \times 12,69}{m} \ldots(1) & \\
\text { Keterangan: } & \\
\mathrm{N}= & \text { normalitas larutan standar natrium } \\
& \text { tiosulfat } 0,1 \mathrm{~N} \\
\mathrm{~V}_{0}= & \text { volume larutan tio } 0,1 \mathrm{~N} \text { yang } \\
& \text { digunakan untuk titrasi blanko }(\mathrm{ml}) \\
\mathrm{V}_{1}= & \text { volume larutan tio } 0,1 \mathrm{~N} \text { yang } \\
& \text { digunakan untuk titrasi contoh }(\mathrm{ml}) \\
\mathrm{m}= & \text { bobot contoh }(\mathrm{g})
\end{aligned}
$$

\subsubsection{Bilangan Peroksida}

Bilangan peroksida dianalisis dengan mengacu pada SNI 01-3555-1994 tentang cara uji minyak dan lemak. Sebanyak $0,3 \mathrm{~g}$ contoh ditambahkan $10 \mathrm{ml}$ kloroform. Larutan kemudian ditambahkan asam asetat glasial sebanyak $15 \mathrm{ml}$ dan kalium iodida jenuh $1 \mathrm{ml}$, dikocok selama 5 menit pada tempat gelap di suhu $15^{\circ} \mathrm{C}-25^{\circ} \mathrm{C}$. Larutan Kembali ditambahkan 75 ml akuades dan dikocok. Terakhir, sampel dititrasi dengan larutan standar natrium tiosulfat $0,02 \mathrm{~N}$ dan indikator berupa larutan kanji. Perhitungan bilangan peroksida dengan rumus sebagai berikut:
Bilangan peroksida $\left(\frac{m g}{k g}\right)=\frac{(V 1-V 0) \times N}{m} \times$ 1000

Keterangan:

$$
\begin{aligned}
\mathrm{V}_{0}= & \text { volume larutan natrium tiosulfat yang } \\
& \text { digunakan untuk titrasi blanko }(\mathrm{ml}) \\
\mathrm{V}_{1}= & \text { volume larutan natrium tiosulfat yang } \\
& \text { digunakan untuk titrasi contoh }(\mathrm{ml}) \\
\mathrm{m}= & \text { bobot contoh }(\mathrm{g})
\end{aligned}
$$

\subsubsection{Asam Lemak Bebas (Free fatty acid)}

Asam lemak bebas dianalisis dengan mengacu pada AOAC, (2000) yaitu secara titrimetri. Sebanyak $40 \mathrm{~g}$ VCO ditambahkan $50 \mathrm{ml}$ etanol. Larutan tersebut kemudian ditambahkan 3-5 tetes indikator PP dan dititrasi dengan larutan standar $\mathrm{NaOH} 0,1$ $\mathrm{N}$. Asam lemak bebas dihitung dengan rumus sebagai berikut:

Asam lemak bebas (sebagai asam laurat $)=$ $\underline{V \times N \times 200}$

$m \times 10$

$$
\begin{aligned}
\text { Keterangan: } \\
\begin{aligned}
\mathrm{V}= & \text { volume } \mathrm{NaOH} \text { yang diperlukan untuk } \\
& \text { titrasi }(\mathrm{ml}) \\
\mathrm{N}= & \text { normalitas } \mathrm{NaOH} \\
\mathrm{m}= & \text { bobot contoh }(\mathrm{g}) \\
& 200 \text { adalah bobot molekul asam laurat }
\end{aligned}
\end{aligned}
$$

\subsubsection{Komponen Asam Lemak}

Komponen asam lemak yang dianalisis adalah asam laurat, asam miristat, asam oleat, dan asam linoleat sesuai AOAC (2000). Sebanyak $50 \mathrm{mg}$ sampel setara lemak dimasukkan ke dalam vial ulir $20 \mathrm{ml}$. Sampel kemudian ditambahkan MTBE dan larutan transesterifikasi (larutan ditambahkan dan dihitung waktunya). Setelah 10 detik, vial dibuka dan ditambahkan heksana dan larutan netralisasi. Sampel disentrifugasi dan diambil fase organik ke dalam vial 2 $\mathrm{ml}$. Sampel diinjeksikan ke dalam sistem GC-FID (Perkin Elmer). Kondisi pengukuran instrumen yang digunakan dalam pengujian ini yaitu suhu inlet $240^{\circ} \mathrm{C}$, 
mode injeksi split, volume injeksi 1,0 $\mu \mathrm{L}$; kondisi kolom dengan gas pembawa helium dan kolom kapiler DB FastFAME; oven program dengan gradien suhu 50-230 ${ }^{\circ} \mathrm{C}$; detektor FID, suhu detektor $240{ }^{\circ} \mathrm{C}, \mathrm{H} 2$ flow $30 \mathrm{ml} /$ menit, dan air flow $300 \mathrm{ml} /$ menit. Hasil diinterpretasikan melihat puncak kromatogram dari hasil pengukuran sampel yaitu puncak asam lemak berantai $\mathrm{C}_{4}-\mathrm{C}_{24}$ yang diketahui dengan cara membandingkan waktu retensi setiap komponen asam lemak dari sampel dengan waktu retensi setiap komponen asam lemak dari standar.

\section{HASIL DAN PEMBAHASAN}

\subsection{Visual VCO yang Diperoleh}

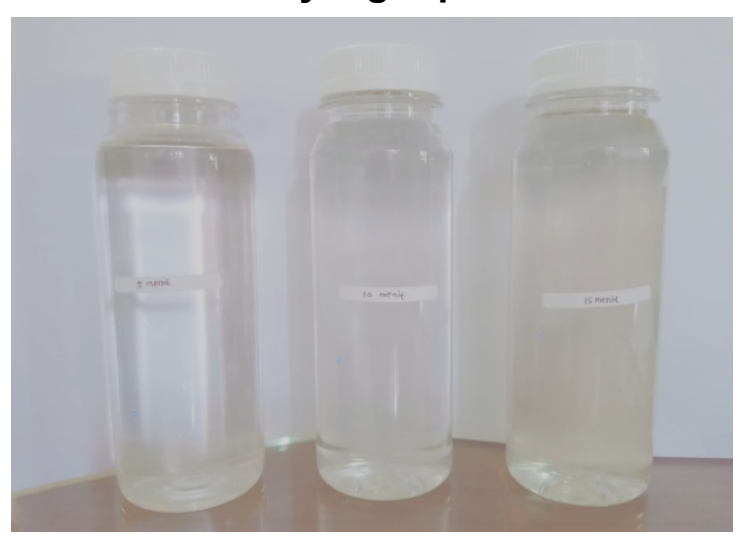

Gambar 1. Penampakan Fisik VCO yang Diperoleh

Hasil VCO dilakukan analisis terhadap bau, rasa, dan warna sesuai dengan SNI 7381:2007 tentang Minyak kelapa virgin (VCO). Gambar 1 menunjukkan VCO yang dihasilkan memiliki penampakan visual jernih dan transparan untuk ketiga variabel yang berbeda, dengan urutan $5,10,15$ menit dari kiri ke kanan gambar. Penampakan dinyatakan "normal" apabila tidak muncul warna lain atau kuning pucat (SNI, 2007). Hal tersebut menunjukkan bahwa tidak ada pengotor yang terdapat dalam VCO. Contoh pengotor di antaranya adalah air, yang akan menghasilkan endapan putih. Untuk parameter bau dan rasa, keberadaan air akan mengakibatkan adanya bau dan rasa tengik. Endapan atau gumpalan dapat disebabkan oleh proses penyaringan yang tidak sempurna sehingga masih ada protein berupa komponen blondo. Proses yang terlewat ini akan mempengaruhi kualitas VCO (Marlina et al., 2017).

\subsection{Rendemen}

Rendemen didapatkan dengan cara membandingkan bobot minyak yang dihasilkan dan bobot krim yang digunakan. Tabel 1 menunjukkan hasil rendemen dalam penelitian ini.

Rendemen dihitung untuk mengetahui banyaknya VCO yang dihasilkan dengan menggunakan cara teknik mekanik (blender). Rendemen tertinggi diperoleh pada variabel lama waktu blender 10 menit yakni sebesar $34,37 \%$. Rendemen yang didapatkan lebih banyak dibandingkan metode Wardani (2007) yang menghasilkan rendemen terbanyak di waktu 15 menit yaitu $20,05 \%$. Hasil rendemen menurun kembali pada lama waktu 15 menit yaitu $25 \%$. Kondisi perlakuan mekanik dengan blender mengakibatkan pecahnya emulsi sehingga minyak terpisah dan menghasilkan VCO.

Tabel 1. Rendemen VCO

\begin{tabular}{llllc}
\hline $\begin{array}{l}\text { Lama Waktu } \\
\text { Proses Mekanik } \\
\text { (menit) }\end{array}$ & $\begin{array}{l}\text { Jumlah Krim } \\
(\mathrm{mL})\end{array}$ & $\begin{array}{l}\text { Jumlah } \\
\text { yang } \\
\text { dihasilkan }(\mathrm{mL})\end{array}$ & $\begin{array}{l}\text { VCO } \\
\text { VCO (\%) }\end{array}$ & $\begin{array}{l}\text { Rendemen } \\
\text { menurut Wardani } \\
(2007)(\%)\end{array}$ \\
\hline 5 & 3600 & 1000 & 27,78 & 10,12 \\
\hline 10 & 2500 & 859,3 & 34,37 & 6,19 \\
\hline 15 & 2400 & 600 & 25 & 20,05 \\
\hline
\end{tabular}


Kondisi optimal tersebut tercapai karena kehilangan stabilitas protein dalam santan, molekul hidrofobik menuju keluar dan hidrofilik tergabung kedalam mengakibatkan koagulasi sehingga minyak dan air terpisah (Winarno 1997). Perlakuan waktu di atas 10 menit telah mencapai kejenuhan sehingga rendemen VCO pada menit ke-15 kian menurun.

\subsection{Bilangan lod}

Tabel 2. Hasil Uji Bilangan lod VCO yang Dihasilkan

\begin{tabular}{lll}
\hline $\begin{array}{l}\text { Lama Waktu } \\
\begin{array}{l}\text { Proses } \\
\text { Mekanik } \\
\text { (menit) }\end{array}\end{array}$ & $\begin{array}{l}\text { Bilangan } \\
\text { lod }(\mathrm{gr} \text { iod/ } \\
100 \mathrm{~g})\end{array}$ & $\begin{array}{l}\text { Bilangan iod } \\
\text { menurut Wardani } \\
(2007)(\mathrm{g} \text { iod } / 100 \mathrm{~g})\end{array}$ \\
\hline 5 & 7,17 & 0,18 \\
\hline 10 & 7,58 & 0,08 \\
\hline 15 & 7,68 & 0,08 \\
\hline
\end{tabular}

Banyaknya iod yang diikat menunjukkan banyaknya ikatan rangkap. Angka iod dinyatakan sebagai banyaknya gram iod yang diikat oleh $100 \mathrm{~g}$ minyak atau lemak (Budiman et al., 2012). Bilangan ini berfungsi untuk menunjukkan ketidakjenuhan lemak. Hasil bilangan iod VCO yang dihasilkan pada penelitian ini dapat dilihat pada Tabel 2. Hasil uji bilangan iod VCO yang diperoleh berkisar antara 7,17 - 7,68 g iod/100 g. Hal tersebut berarti bilangan iod dengan teknik mekanik (blender) sesuai dengan metode penelitian ini memenuhi standar yang ditetapkan (SNI 7381:2008) dengan bilangan iod VCO berkisar antara 4,1-11 $\mathrm{g}$ iod/100 $\mathrm{g}$, sedangkan untuk bilangan iod menurut Wardani (2007) tidak memenuhi standar yaitu 0,$18 ; 0,08$; dan $0,08 \mathrm{~g}$ iod/100 $\mathrm{g}$.

\subsection{Bilangan Peroksida}

Bilangan peroksida menentukan tingkat kerusakan minyak. Hal ini ditunjukkan dengan hidroperoksida yang terbentuk akibat adanya proses oksidasi primer dalam minyak. Bau tengik yang biasanya ditemukan pada minyak disebabkan oleh tingkat ketidakjenuhannya, yang dapat diukur dengan mengetahui bilangan peroksidanya. Ketidakjenuhan ini mempengaruhi kualitas minyak karena beresiko toksik terhadap kesehatan seperti penyakit degeneratif (Ayu et al., 2019).

Tabel 3. Hasil Uji Bilangan Peroksida VCO yang Dihasilkan

\begin{tabular}{llll}
\hline No & $\begin{array}{l}\text { Lama Waktu } \\
\text { Proses } \\
\text { Mekanik } \\
\text { (menit) }\end{array}$ & $\begin{array}{l}\text { Bilangan } \\
\text { Peroksid } \\
\text { a } \\
(\mathrm{mEq} / \mathrm{kg})\end{array}$ & $\begin{array}{l}\text { Bilangan } \\
\text { peroksida } \\
\text { menurut } \\
\text { Wardani } \\
(2007)\end{array}$ \\
\hline 1. & 5 & 0 & 0 \\
\hline 2. & 10 & 0 & 0 \\
\hline 3. & 15 & 0 & 0 \\
\hline
\end{tabular}

Tabel 3 menunjukkan hasil uji bilangan peroksida pada VCO yang melalui proses mekanik selama 5, 10, 15 menit. Hasil uji bilangan peroksida VCO yang dihasilkan pada penelitian ini adalah 0 $\mathrm{mEq} / \mathrm{kg}$ pada semua variabel. Hal tersebut di atas menunjukkan bahwa bilangan peroksida VCO yang diperoleh memenuhi standar yang ditetapkan (SNI 7381:2008) yang mana bilangan peroksida pada VCO maksimal $2 \mathrm{mEq} / \mathrm{kg}$. Semakin rendah bilangan peroksida maka kualitas minyak akan semakin baik (Maradesa et al., 2014).

Pada penelitian ini diperoleh bilangan peroksida $0 \mathrm{mEq} / \mathrm{kg}$. Hal tersebut dipengaruhi oleh tidak adanya proses pemanasan dalam pembuatan VCO dan perlakuan yang dilakukan pada penelitian ini di suhu kamar. Semakin tinggi suhu pada saat proses pembuatan VCO dapat membuat semakin cepat terjadi reaksi oksidasi. Semakin cepat VCO kontak langsung dengan oksigen (reaksi oksidasi), maka reaksi pembentukan radikal bebas yang selanjutnya diubah menjadi hidroperoksida akan semakin meningkat. sehingga membuat bilangan peroksida semakin tinggi (Winarti et al., 2007). Terjadinya reaksi oksidasi dapat mengakibatkan bau tengik pada minyak yang menandai terjadinya kerusakan (Maradesa et al., 2014). 


\subsection{Asam Lemak Bebas}

Tabel 4. Hasil Uji Asam Lemak Bebas VCO yang Dihasilkan

\begin{tabular}{llll}
\hline No. & $\begin{array}{l}\text { Lama Waktu } \\
\text { Proses } \\
\begin{array}{l}\text { Mekanik } \\
\text { (menit) }\end{array}\end{array}$ & $\begin{array}{l}\text { Asam } \\
\text { Lemak } \\
\text { Bebas } \\
(\%)\end{array}$ & $\begin{array}{l}\text { Asam Lemak } \\
\text { Bebas menurut } \\
\text { Wardani (2007) }\end{array}$ \\
\hline 1. & 5 & 0,12 & 0,35 \\
\hline 2. & 10 & 0,079 & 0,31 \\
\hline 3. & 15 & 0,079 & 0,29 \\
\hline
\end{tabular}

Bilangan asam merupakan parameter lain yang digunakan dalam menentukan kualitas mutu VCO. Bilangan asam menunjukkan seberapa banyak asam lemak bebas pada minyak. Untuk itu, bilangan asam juga menentukan kualitas mutu dari minyak, bilangan asam yang tinggi menunjukkan kualitas mutu minyak yang rendah, begitu pula sebaliknya (Ayu et al., 2019). Semakin tinggi bilangan asam, mengartikan bahwa semakin banyak asam-asam lemak yang terlepas dari ikatan selama produksi minyak. Air berperan penting terhadap terjadinya proses hidrolisis. Keberadaan air akan membuat lemak terhidrolisis menghasilkan gliserol dan asam lemak bebas (Maradesa et al., 2014). Hasil uji bilangan asam bebas VCO yang dihasilkan dapat dilihat pada Tabel 4.

Kadar asam lemak bebas sesuai dengan syarat mutu VCO (SNI 7381:2008) adalah maksimal $0,2 \%$. Dilihat dari data pada Tabel 4, hasil uji asam lemak bebas VCO yang dihasilkan memenuhi persyaratan mutu untuk VCO karena hasilnya di bawah 0,2\%, menghasilkan asam lemak bebas yang lebih baik dibandingkan metode yang dimodifikasi Wardani (2007) yaitu melebihi 0,2\%. Proses mekanik mengakibatkan adanya tumbukan dan gesekan tiap molekul sehingga mengakibatkan terjadinya penguapan rendemen yang dihasilkan, hal ini ditunjukkan dengan menurunnya asam lemak bebas setelah menit ke-5 (Aprilasani dan Adiwarna, 2014).

\subsection{Komposisi Asam Lemak (Asam Laurat, Asam Miristat, Asam Oleat dan Asam Linoleat)}

Pada Tabel 5 ditampilkan kandungan asam laurat VCO semua variabel pada penelitian ini sesuai dengan syarat mutu yang ditetapkan (SNI 7381:2008) yakni $45,1-53,2 \%$. Asam laurat termasuk ke dalam jenis asam lemak jenuh, yang biasa ditemukan dalam minyak kelapa murni atau VCO. Asam laurat merupakan asam lemak jenuh rantai sedang (medium chain fatty acid, MCFA) dengan 12 atom karbon (Pratiwi \& Yunus, 2018). Komposisi asam lemak tertinggi dalam minyak kelapa murni adalah asam laurat yang berfungsi dapat memberi gizi serta melindungi tubuh dari penyakit menular dan penyakit degeneratif (Rindawati et al., 2014). Asam laurat yang terdapat dalam VCO diketahui memiliki

Tabel 5. Komposisi Asam Laurat, Asam Miristat, Asam Oleat dan Asam Linoleat pada VCO yang Dihasilkan

\begin{tabular}{llllll}
\hline \multirow{2}{*}{$\begin{array}{l}\text { No } \\
\text {. Jenis Asam }\end{array}$} & \begin{tabular}{l} 
Kemak \\
\cline { 3 - 6 }
\end{tabular} & $\begin{array}{l}\text { VCO dengan } \\
\text { lama waktu } \\
\text { blender 5 menit }\end{array}$ & $\begin{array}{l}\text { VCO dengan } \\
\text { lama waktu } \\
\text { blender 10 } \\
\text { menit }\end{array}$ & $\begin{array}{l}\text { VCO dengan } \\
\text { lama waktu } \\
\text { blender 15 } \\
\text { menit }\end{array}$ & $\begin{array}{l}\text { SNI } \\
7381: 2008\end{array}$ \\
\hline 1. & Asam Laurat & 48,80 & 47,93 & 47,55 & $45,1-53,2$ \\
\hline 2. & Asam Miristat & 16,63 & 17,66 & 18,71 & $16,8-21$ \\
\hline 3. & Asam Oleat & 5,59 & 5,62 & 6,09 & $5,0-10,0$ \\
\hline 4. & Asam Linoleat & 1,35 & 1,46 & 1,5 & $1,0-2,5$ \\
\hline
\end{tabular}


manfaat kesehatan dan kecantikan. Asam laurat ini memiliki sifat antibakteri, antijamur serta sangat bermanfaat untuk menjaga kekebalan tubuh (Ardianto \& Mutiah, 2018). Pada industri kosmetik digunakan sebagai pelembab dan pelembut, dan juga digunakan pada industri sabun dan sampo (Pratiwi \& Yunus, 2018). Asam lemak laurat pada VCO dengan kandungan yang setara dengan kandungan asam lemak laurat pada air susu ibu (ASI), mengindikasikan adanya suatu peran penting dalam hal pembentukan antibodi pada tubuh manusia. Oleh karena itu, semakin tinggi kandungan asam lemak laurat pada makanan yang dikonsumsi, maka semakin tinggi pula nilai manfaatnya bagi kesehatan, apabila ditinjau dari aspek fungsi ASI dalam meningkatkan nutrisi, kesehatan dan imunitas (Widiada, 2015).

Berdasarkan Tabel 5, hasil uji kandungan asam miristat pada VCO dengan lama waktu blender 10 dan 15 menit memenuhi syarat mutu VCO yang ditetapkan (SNI 7381:2008), tetapi untuk VCO dengan lama waktu blender 5 menit, hasil kadar asam miristatnya sedikit di bawah standar yakni $16,63 \%$ sedangkan syarat mutu yang ditetapkan untuk asam miristat pada VCO yakni $16,8-21 \%$.

Asam oleat dan asam linoleat adalah jenis asam lemak tak jenuh yang terdapat dalam VCO. Sifat tak jenuh minyak disebabkan oleh keberadaan ikatan rangkap, yang pada akhirnya akan berpengaruh terhadap reaksi oksidasi penyebab ketengikan (Sanjiwani et. al, 2014). SNI 7381:2008 memberikan persyaratan kadar asam oleat dalam sampel VCO yaitu antara $5-10 \%$ dan untuk asam linoleat yaitu antara $1-2,5 \%$. Pada Tabel 5, kadar asam oleat dan linoleat telah memenuhi persyaratan SNI 7381:2008.

\section{KESIMPULAN DAN SARAN}

Penelitian ini menunjukkan bahwa produksi VCO menggunakan teknik mekanik menggunakan blender hasil modifikasi Wardani (2007) menghasilkan mutu VCO yang sesuai dengan SNI 7381:2008. Apabila dibandingkan dengan metode Wardani (2007), metode tersebut tidak memenuhi persyaratan SNI 72381:2008. Hal ini menunjukkan bahwa metode ini dapat diimplementasikan sesuai kebutuhan petani lokal kelapa dalam Kalimantan Barat dalam skala industri rumah tangga.

\section{DAFTAR PUSTAKA}

AOAC. (2000). Analysis of Oil and Fat, Chapter 41, (pp 26-28). USA: AOAC International.

Agarwal, R.K., \& Bosco,S.J.D. (2017). Extraction processes of virgin coconut oil. MOJ Food Prosessing \& Technology, 4(2), 1-3, htpps://doi.org/10.15406/mojfpt.201 7.04.00087

Alitprakoso, D., Mulyawati, K., Aribowo, K., \& Pamularsih, S. (2010). Agitator Untuk Pembuatan Minyak Kelapa Murni (Virgin Coconut Oil) Dari Santan Buah Kelapa Secara Batch. In Uni.

Ardianto, A., \& Mutiah, H. (2018). Analisis Perbandingan Asam Lemak VCO dengan Metode Fermentasi dari Berbagai Varietas Kelapa. Bioeduscience, 2(2), 122-128. https://doi.org/10.29405/j.bes/22122 $-1282486$

Aprilasani, Z., \& Adiwarna. (2014). Pengaruh lama pengadukan dengan variasi penambahan asam asetat dalam pembuatan Virgin Coconut Oil (VCO) dari buah kelapa. KONVERSI, 3(1), 1-11.

Asmawit. (2010). Optimasi Proses Pembuatan VCO untuk Memenuhi Mutu Kosmetik Lulur. Biopropal Industri, 1(2), 1-8.

Arisanti, D. dan I.O. Angelia. (2020). Peningkatan Kualitas Minyak Kelapa Murni (VCO) Terfermentasi Kultur Kering Bakteri Asam Laktat (BAL) Terhadap Rendemen dan Kadar Air. Jurnal Pertanian, 11(1), 21-24 
Ayu, D., Pramitha, I., \& Juliadi, D. (2019). Pengaruh Suhu Terhadap Bilangan Peroksida dan Asam Lemak Bebas Pada VCO (Virgin Coconut Oil) Hasil Fermentasi Alami. Cakra Kimia (Indonesian E-Journal of Applied Chemistry, 7(2), 149-154.

BPS. (2019). Kalimantan Barat dalam Angka 2019. BPS: Kalbar.

Dali, A., Harimu, \& Simbiti, L. (2015). Pengaruh Kecepatan Putar Pengadukan dan Waktu Pendiaman Terhadap Rendemen dan Kualitas Minyak Kelapa Murni (VCO). Jurnal Al Kimia, 3(1), 48-58.

Dewi, N. Pt. P. M. S., Bogoriani, N. W., \& Suaniti, N. M. (2019). Identifikasi Dan Karakterisasi Profil Asam Lemak Virgin Coconut Oil Dengan Penambahan Ekstrak Etanol Kunyit Putih (Curcuma zedoaria Rosc.). Chimica et Natura Acta, 7(3), 125131.

https://doi.org/10.24198/cna.v7.n3.2 6288

Maradesa, R. P., Fatimah, F., \& Sangi, M. S. (2014). Kualitas Virgin Coconut Oil (VCO) Sebagai Minyak Goreng yang Dibuat dengan Metode Pengadukan dengan Adanya Penambahan Kemangi (Ocimum sanctum L.). Jurnal Mipa Unsrat Online, 3(1), 44-48.

Marlina, D., Wijayanti, D., Yudiastari, I., \& Safitri, L. (2017). Pembuatan Virgin Coconut Oil dari Kelapa Hibrida menggunakan metode Penggaraman Dengan $\mathrm{NaCl}$ dan Garam Dapur. Jumal Chemurgy, 1(2), 7-12.

Mahmud, Z., Ferry, Y. (2005). Prospek pengolahan hasil samping buah kelapa. Perspektif, 4(2), 55-63.

Muslihin, \& Riyani, C. (2018). Mengolah VCO (Virgin Coconut Oil) dengan Pengadukan Mekanik. Agrisains, 4(2), 6-9.

Novarianto, H., \& Tulalo, M. Kandungan asam laurat pada berbagai varietas kelapa sebagai bahan baku VCO. Jurnal Littri, 13(1), 28-33.

Pranata, D., Ardiningsih, P., Rahmalia, W., \& Syahbanu, I. (2020). Ekstraksi
Minyak Kelapa Murni Dengan Metode Pengadukan dan Cold Pressed. J. Pure App. Chem, 3(2), 11-17.

http://jurnal.untan.ac.id/index.php/lJ oPAC

Pratiwi, I., \& Yunus, M. (2018). Pemisahan Asam Laurat dari Virgin Coconut Oil (VCO) dengan Metode Saponifikasi dan Sonikasi. Prosiding Seminar Nasional Universitas Negeri Lhokseumawe, 2(1), A235A239Rethinam, P. (2018). International scenario of coconut sector. In Nampoothiri, K.U.K., Krishnakumar, V., Thampan, P.K., Nair, M.A. The Coconut Palm (Cocos nucifera L.) - Research and Development Perspectives (pp 2156). USA: Springer.

Rindawati, Perasulmi, \& Kurniawan, E. (2014). Studi Perbandingan Pembuatan VCO (Virgin Coconut Oil) Sistem Enzimatis dan Pancingan Terhadap Karakteristik Minyak Kelapa Murni yang Dihasilkan. Indonesian Journal of Laboratory, 2(2), 25-32.

Sanjiwani, P., Widjaja, I.N.K., \& Warditiani, N.K. (2014). Analisis kuantitatif asam lemak tak jenuh pada Virgin Coconut Oil (VCO) yang dibuat dengan penambahan sari getah buah papaya (Carica papaya L.). (Skripsi Sarjana). Universitas Udayana, Bali.

Wardani, I. (2007). Uji kualitas VCO berdasarkan cara pembuatan dari proses pengadukan tanpa pemancingan dan proses pengadukan dengan pemancingan. (Skripsi Sarjana). Universitas Negeri Semarang, Semarang.

Widiada, I. (2015). perbandingan komposisi asam lemak Virgin Coconut Oil (VCO) hasil fermentasi starter ragi roti dengan vco hasil pabrikan serta aktivitas antibakterinya pada bakteri penyebab diare.(Tugas Akhir). Poltekkes Kemenkes Mataram, Mataram.

Winarti, S., Jariyah, \& Purnomo. (2007). Proses Pembuatan VCO (Virgin 
Jurnal Riset Industri Hasil Hutan Vol.13, No.2, Desember 2021: 133 - 142

Coconut Oil) Secara Enzimatis Menggunakan Papain Kasar. Jurnal

Teknologi Pertanian, 8(2), 136-141.

Winarno, F.G. (1997). Kimia Pangan dan

Gizi. Jakarta: Gramedia. 